\title{
Differential release of LH and FSH in cyclic mares in response to synthetic Gn-RH
}

\author{
J. P. Foster*, Margaret J. Evans and C. H. G. Irvine \\ Department of Veterinary Science, Lincoln College, Canterbury, New Zealand
}

\begin{abstract}
Summary. Mares at different stages of the oestrous cycle were given a single intravenous injection of $0.5 \mathrm{mg}$ synthetic $\mathrm{Gn}-\mathrm{RH}$.

The mean area of the induced LH peak was significantly less at mid-cycle (Day 10-11) than at any other time. The mean height of the LH peak above preinjection concentration was greater at late oestrus and early cycle (Day 5-6) than at midcycle and early oestrus. There were no significant differences in mean FSH responses. The LH :FSH ratio for both height and area of induced peaks was significantly less at mid-cycle than at other times of injection. These results suggest that one releasing hormone could cause the release of both FSH and LH in the normal cyclic mare.
\end{abstract}

\section{Introduction}

The pattern of release of gonadotrophins during the oestrous cycle of the mare has been shown to be different from that of other large domestic species. Serum luteinizing hormone (LH) concentrations in the mare do not show a large preovulatory peak of only a few hours duration but increase gradually during the first 4-5 days of oestrus, and reach a peak 1 or 2 days after ovulation (Pattison, Chen \& King, 1972; Whitmore, Wentworth \& Ginther, 1973; Noden, Oxender \& Hafs, 1974; Evans \& Irvine, 1975; Geschwind, Dewey, Hughes, Evans \& Stabenfeldt, 1975; Nett, Holtan \& Estergreen, 1975; Nett, Pickett, Seidel \& Voss, 1976). There are two distinct surges of FSH in the serum of mares, one in late oestrus or early dioestrus and one in mid- to late-dioestrus (Evans \& Irvine, 1975). The former is coincident with increased LH release but the latter occurs at a time when plasma $\mathrm{LH}$ concentration is basal. It is possible that this differential release is due to separate FSH and LH releasing hormones. However, preliminary experiments in acyclic mares suggest that one gonadotrophin-releasing hormone can induce differential FSH and LH release (Evans \& Irvine, 1976a). This would be possible if, for example, pituitary responsiveness to the releasing hormone changes separately for LH and FSH in different reproductive situations.

The pituitary responsiveness of mares to synthetic gonadotrophin-releasing hormone (Gn$\mathrm{RH})$ was therefore tested at various stages of the oestrous cycle. This material had previously been shown to release LH and FSH in seasonally anoestrous mares (Evans \& Irvine, 1976b, 1977).

\section{Materials and Methods}

Experiments. Five Standardbred mares grazing on pasture at Lincoln College Research Farm were bled daily (in the late morning or early afternoon) by jugular venepuncture throughout the

* Present address: Department of Physiology and Environmental Studies, University of Nottingham School of Agriculture, Sutton Bonington, Loughborough, Leics LE12 5RD, U.K. 
experiment (October 1977 to April 1978, a period which encompassed the physiological breeding season). Occurrence of oestrus and ovulation was determined by regular teasing by a stallion, palpation of the ovaries per rectum, and serum progesterone concentrations. These mares were used for more than one treatment group but at least one complete normal oestrous cycle was allowed to elapse between each treatment. Some mares developed a persistent corpus luteum and lysis was induced by a prostaglandin injection. In these mares $\mathrm{Gn}-\mathrm{RH}$ treatment was not given until the following oestrous cycle to avoid any possible effect of the prostaglandin injection on the results obtained. In addition 4 mares from the Nevele $\mathrm{R}$ Stud were used once in the experiment at a known stage of oestrus.

Groups of mares were given an intravenous injection of $0.5 \mathrm{mg} \mathrm{Gn}-\mathrm{RH}$ (Hoechst Pharmaceuticals Ltd.) at 09:00 h during early oestrus, late oestrus, Day 5-6 after ovulation (early cycle) or Day 10-11 after ovulation (mid-cycle). The stage of the cycle at which Gn-RH was given was determined by comparing the daily serum $\mathrm{FSH}, \mathrm{LH}$ and progesterone changes before injection with the levels in the normal cycle. Each mare given $\mathrm{Gn}-\mathrm{RH}$ was sampled by jugular venepuncture at $-0.5,-0.25,0,0.25,0.5,0.75,1,1.5,2,2.5,3,4,5,6,8$, and $10 \mathrm{~h}$ in relation to the injection (Time 0). The blood samples were allowed to clot overnight at $4^{\circ} \mathrm{C}$ and the serum was then collected and stored at $-20^{\circ} \mathrm{C}$ until assay.

Hormone assays. Serum FSH and LH concentrations were determined in all samples. FSH was measured by a previously described radioimmunoassay method (Evans \& Irvine, 1976b) using anti-human FSH antiserum with labelled human FSH. The Nuti equine FSH used as standard had a potency of 90 times that of NIH-FSH-S1 when determined by the SteelmanPohley assay (Braselton \& McShan, 1970). At a final dilution of 1:31500, the antibody specifically bound $16-22 \%$ of the ${ }^{125}$ I-labelled $\mathrm{hFSH}$ - non-specific binding was $1.67 \pm 0.2 \%$. The intra- and inter-assay coefficients of variation were 12.3 and $12.8 \%$ respectively.

Serum LH concentrations were measured using a modification of the method of Noden et al. (1974). At a final dilution of 1:213 000 the anti-ovine $\mathrm{LH}$ antiserum specifically bound $15-35 \%$ of the ${ }^{125}$ I-labelled oLH; non-specific binding was $3.18 \pm 1.63 \%$. The Nuti equine LH used as standard had 5.3 times the activity of NIH-LH-S1 when assayed by the ovarian ascorbic acid depletion assay and 33.6 times the activity when determined by the ventral prostate weight assay (Braselton \& McShan, 1970). The intra- and inter-assay coefficients of variation were 11.6 and $15.6 \%$ respectively. The progesterone concentration was measured in a proportion of the daily samples so that the serum concentration was known every 3rd day in mid-cycle, every 2 nd day before, during and after oestrus, and daily around the time of Gn-RH treatment. The method used was that of Berwyn-Jones \& Irvine (1974).

The LH and FSH responses to Gn-RH injection were assessed in terms of height and area of the hormone peaks above the preinjection baseline. The area was measured in arbitrary units on graph paper. The duration of the response was not used since this was sometimes greater than the time of sampling and at other times was difficult to assess accurately. In animals in which the concentration had not returned to baseline by the end of the sampling period ( 2 occasions) the area was also underestimated, but this underestimate would have been much smaller as a percentage of the total area than would be the case for the underestimate in response duration.

The actual values for LH and FSH cannot be directly compared, but the LH:FSH ratio for both peak height and area gives a comparison of the relative changes in LH and FSH responsiveness to Gn-RH during the cycle. The means of the different groups were compared by Student's $t$ test.

\section{Results and Discussion}

The FSH and LH concentrations in 5 normal oestrous cycles in 3 mares are shown in Text-fig. 1(a). Two surges of FSH occurred in each cycle, one around the time of oestrus and one at midcycle. The timing of both these was variable between and within animals and hence the mean 


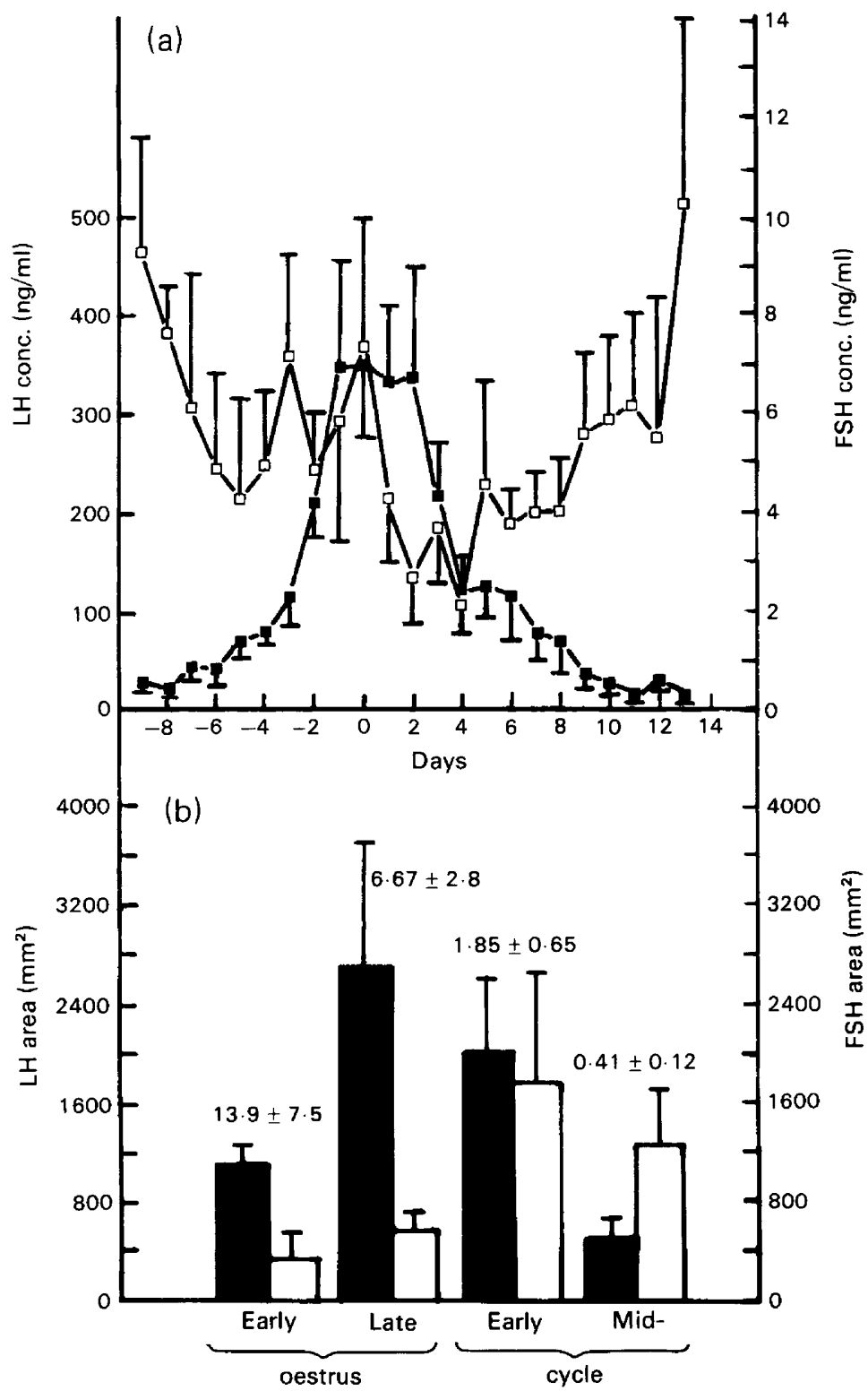

Text-fig. 1. Mean \pm s.e.m. changes in (a) serum LH ( $\square$ ) and FSH ( $\square$ ) concentrations in 5 normal oestrous cycles from 3 different mares (oestrus was approximately from 5 days before ovulation until the day of ovulation, Day 0 ) and (b) areas of LH (solid columns) and FSH (open columns) peaks induced by intravenous Gn-RH injection at various stages of the cycle. The mean $( \pm$ s.e.m.) LH : FSH ratio is shown above each pair of columns.

serum FSH graph shows less distinct surges than individual animals. This also accounts for the large standard error in the FSH values. This pattern of FSH concentrations was similar to that found previously, although the lowest concentrations of the cycle occurred following the early cycle surge rather than in early oestrus as reported by Evans \& Irvine (1975). Serum LH always showed an increase during oestrus which lasted for several days, reached a peak in late oestrus, and did not start to decline until 1 or 2 days after ovulation. This pattern is similar to that reported by Noden et al. (1975) who used a comparable assay system. 
There was no significant difference in the FSH responses at various times of the cycle to $\mathrm{Gn}$ RH injection (Table 1, Text-fig. 1b). However, all the higher responses were in the early and midcycle groups and there was a very low FSH response in two of the animals injected in early oestrus. Thus if anything the FSH response was greater at mid-cycle than it was at oestrus.

The LH response to synthetic Gn-RH in terms of area of the induced peak was significantly less at mid-cycle than at all the other times tested (Text-fig. 1b). No other times of the cycle had a significantly different response in terms of area, but the height of the induced LH peak was significantly greater when the injection was given at late oestrus than when it was given in early oestrus (Table 1), despite the fact that the start of the natural increase in LH concentration was imminent at the latter time. In other species the responsiveness of the pituitary gland to a single injection of synthetic or purified Gn-RH is generally highest at times when the preovulatory LH release is imminent, for example in the rat (Cooper, Fawcett \& McCann, 1973), golden hamster (Arimura, Debeljuk \& Schally, 1972), rhesus monkey (Krey, Yamaji, Butler \& Knobil, 1972) and sheep (Reeves, Arimura \& Schally, 1971; Foster \& Crighton, 1976a, b). In the present experiment the largest $\mathrm{LH}$ response to $\mathrm{Gn}-\mathrm{RH}$ was, however, at late oestrus which coincides with the time when the serum LH concentration is at its highest. Since the response is measured in terms of size of peak above preinjection values this shows that although the LH concentration is high when the injection is given at late oestrus it is capable of being stimulated further. The $\mathrm{LH}$ response to $\mathrm{Gn}-\mathrm{RH}$ injection was still high in the early cycle when the natural serum $\mathrm{LH}$ concentration was declining which is different from the situation in the sheep in which a Gn-RH injection after the natural preovulatory $\mathrm{LH}$ peak induces a much lower $\mathrm{LH}$ response than does injection at any other time of the oestrous cycle (Foster \& Crighton, 1976b; Foster, 1978).

Table 1. Heights of $\mathrm{LH}$ and FSH peaks (above baseline) induced by synthetic Gn-RH injection at various stages of the oestrous cycle in the mare

\begin{tabular}{lccc}
\hline & \multicolumn{3}{c}{ Height of peak } \\
\cline { 2 - 4 } \multicolumn{1}{c}{ Stage of cycle } & LH & FSH \\
$(\mathrm{ng} / \mathrm{ml})$ & $(\mathrm{ng} / \mathrm{ml})$ & LH : FSH \\
\hline Mid-cycle & 195 & 23 & $8 \cdot 78$ \\
(Day 10-11 after ovulation) & 300 & 52 & $5 \cdot 77$ \\
& 102 & 21 & $4 \cdot 86$ \\
& 160 & 12 & $13 \cdot 33$ \\
Mean \pm s.e.m. & 120 & $7 \cdot 5$ & $16 \cdot 0$ \\
\hline Early oestrus & $175 \pm 35^{\mathrm{a}}$ & $23 \cdot 1 \pm 7 \cdot 8^{\mathrm{a}}$ & $9 \cdot 74 \pm 2 \cdot 2^{\mathrm{a}}$ \\
\hline Mean \pm s.e.m. & 270 & 5 & 54 \\
\hline Late oestrus & 208 & 12 & $17 \cdot 3$ \\
& 145 & 6 & $24 \cdot 17$ \\
Mean \pm s.e.m. & 230 & $1 \cdot 0$ & 230 \\
\hline Early cycle & $213 \pm 26^{\mathrm{a}}$ & $6 \cdot 0 \pm 2 \cdot 27^{\mathrm{a}}$ & $81 \cdot 37 \pm 50 \cdot 1^{\mathrm{a}, \mathrm{b}}$ \\
(Day 5-6 after ovulation) & 660 & 7 & $94 \cdot 29$ \\
Mean \pm s.e.m. & 808 & 6 & $134 \cdot 66$ \\
\hline
\end{tabular}

In each column means with a common superscript are not significantly different $(P>0.05)$. 
The LH : FSH ratio was significantly lower in terms of both height and area, in mares at midcycle compared with those at late oestrus and early in the cycle (Table 1, Text-fig. 1b). The large difference between the mean ratios at mid-cycle and early oestrus failed to reach significance because of the high standard error of the latter.

The dose of Gn-RH used may be important in determining the relative changes in gonadotrophin response during the cycle. In women, Wang, Lasley \& Yen (1976) have shown differences in the magnitude and pattern of gonadotrophin responses to a large dose $(150 \mu \mathrm{g})$ and a small dose $(10 \mu \mathrm{g})$ of Gn-RH during three phases of the menstrual cycle. Thus the results of this type of experiment must be interpreted with caution.

The cyclic mare has an unusual plasma gonadotrophin profile in that there is a large FSH surge during late dioestrus when $\mathrm{LH}$ is at its lowest; also FSH is declining to low levels during oestrus at times when LH is still high (Text-fig. 1a). However the times of maximum responsiveness to Gn-RH for each gonadotrophin coincide with these peaks of the normal cycle (Text-fig. 1b; Table 1). This suggests that a cyclic change in pituitary sensitivity to a single releasing hormone could cause the differential release of FSH and LH that occurs during the natural oestrous cycle.

We thank the National Pituitary Agency, NIMDD, Bethesda, Maryland, U.S.A., for human FSH and LH for iodination and anti-human FSH and LH antiserum; Dr L. Nuti, University of Wisconsin, U.S.A., for equine FSH and LH; Hoechst, Frankfurt (M), Germany, for Gn-RH; I.C.I., New Zealand, for prostaglandin analogue; The Medical Unit, The Princess Margaret Hospital, Christchurch, for assistance with hormone iodination and Bruce Lawson, Joyce Harris and Darrylyn Cummings for their technical assistance.

\section{References}

Arimura, A., Debeljuk, L. \& Schally, A.V. (1972) LH release by $\mathrm{LH}$-releasing hormone in golden hamsters at various stages of estrous cycle. Proc. Soc. exp. Biol. Med. 140, 609-612.

Berwyn-Jones, M.D. \& Irvine, C.H.G. (1974) Induction of luteolysis and oestrus in mares with a synthetic prostaglandin analogue (ICI 81008). N.Z. vet. J. 22 , $107-110$.

Braselton, W.E., Jr \& McShan, W.H. (1970) Purification and properties of follicle stimulating and luteinizing hormones from horse pituitary glands. Archs Biochem. Biophys. 139: 45-58.

Cooper, K.J., Faweett, C.P. \& McCann, S.M. (1973) Variations in pituitary responsiveness to luteinizing hormone releasing factor during the rat oestrous cycle. J. Endocr. 57, 187-188.

Evans, M.J. \& Irvine, C.H.G. (1975) Serum concentrations of FSH, LH and progesterone during the oestrous cycle and early pregnancy in the mare. $J$. Reprod. Fert., Suppl. 23, 193-200.

Evans, M.J. \& Irvine, C.H.G. (1976a) Evidence for the existence of a single gonadotrophin releasing hormone. Proc. 5th Int. Congr. Endocr., Hamburg. Abstr. 160.

Evans, M.J. \& Irvine, C.H.G. (1976b) Measurement of equine follicle stimulating hormone and luteinizing hormone: response of anestrous mares to gonadotrophin releasing hormone. Biol. Reprod. 15, 477484.

Evans, M.J. \& Irvine, C.H.G. (1977) Induction of follicular development, maturation and ovulation by gonadotrophin releasing hormone administration to acyclic mares. Biol. Reprod. 16, 452-462.

Foster, J.P. (1978) The response of the pituitary gland to hypothalamic stimulation. In Control of Ovulation, pp. 101-116. Eds D. B. Crighton, G. R. Foxcroft, N. B. Haynes \& G. E. Lamming. Butterworths, London.

Foster, J.P. \& Crighton, D.B. (1976a) Luteinizing hormone release following injection of synthetic $\mathrm{LH}$ $\mathrm{RH}$ at various stages of the oestrous cycle in the sheep. J. Endocr. 68, $41 P-42 P$.

Foster, J.P. \& Crighton, D.B. (1976b) Pituitary responsiveness to a single injection of synthetic luteinizing hormone releasing hormone before and after the natural preovulatory plasma luteinizing hormone peak in sheep. J. Endocr. 71, 269-270.

Geschwind, I.I., Dewey, R., Hughes, J.P., Evans, J.W. \& Stabenfeldt, G.H. (1975) Plasma LH levels in the mare during the oestrous cycle. J. Reprod. Fert., Suppl. 23, 207-212.

Krey, L.C., Yamaji, T., Butler, W.R. \& Knobil, E. (1972) Phases of the menstrual cycle and responsiveness to synthetic luteinizing hormone releasing factor (LRF) in the rhesus monkey. Fedn Proc. Fedn Am. Socs exp. Biol. 31, Abstr 352.

Nett, T.M., Holtan, D.W. \& Estergreen, N.L. (1975) Levels of $\mathrm{LH}$, prolactin and oestrogens in the serum of post-partum mares. J. Reprod. Fert., Suppl. 23, $201-206$. 
Nett, T.M., Pickett, B.W., Seidel, G.E. \& Voss, J.L. (1976) Levels of luteinizing hormone and progesterone during the estrous cycle and early pregnancy in mares. Biol. Reprod. 14, 412-415.

Noden, P.A., Oxender, W.D. \& Hafs, H.D. (1974). Estrus, ovulation, progesterone and luteinizing hormone after prostaglandin $\mathrm{F} 2 \alpha$ in mares. Proc. Soc. exp. Biol. Med. 145, 145-150.

Noden, P.A., Oxender, W.D. \& Hafs, H.D. (1975) The cycle of oestrus, ovulation and plasma levels of hormones in the mare. J. Reprod. Fert., Suppl. 23, 189-192.

Pattison, M.L., Chen, C.L. \& King, S.L. (1972) Determination of $\mathrm{LH}$ and estradiol-17 $\beta$ surge with reference to the time of ovulation in mares. Biol. Reprod. 7, 136.
Reeves, J.J., Arimura, A. \& Schally, A.V. (1971) Pituitary responsiveness to purified luteinizing hormone-releasing hormone (LH-RH) at various stages of the estrous cycle in sheep. J. Anim. Sci. 32, $123-126$.

Wang, C.F., Lasley, B.L. \& Yen, S.S.C. (1976) Gonadotrophin secretion in response to low and high doses of LRF in normal and hypogonadal women (functional disparity of the gonadotrophs). J. clin. Endocr. Metab. 42, 427-431.

Whitmore, H.L., Wentworth, B.C. \& Ginther, O.J. (1973) Circulating concentrations of luteinizing hormone during estrous cycle of mares as determined by radioimmunoassay. Am. J. vet. Res. 34, 631-636.

Received 6 November 1978 